\title{
SOME CULTURAL ASPECTS OF IMMIGRATION: ITS IMPACT, ESPECIALLY ON OUR ARTS AND SCIENCES
}

\author{
JOHN HARMON BuRMA*
}

For about $5_{50}$ years, the United States pursued a policy of relatively unrestricted immigration. Since 1924 , however, we have pursued a policy of drastically restricted immigration, with the restrictions based on considerations which many persons have believed to be discriminatory, unjust, and not based on facts. In the early I950's, it seemed that changes in this policy might be effected. The final result, the McCarranWalter Act, ${ }^{1}$ however, although undoubtedly a more efficient instrument than the I924 law, ${ }^{2}$ still clashes with the democratic ideals held by most Americans and not only perpetuates most of the injustices of the earlier legislation, but adds new discriminations of its own.

We shall here concern ourselves not with the entire law, but rather with the principle upon which it is based: that it is not desirable for the United States to permit more than a small amount of immigration, and that such immigration should be specifically and unequally allocated among various countries. The assumptions here embodied are that the place of birth of an immigrant is a reliable indication of his capability of becoming a desirable American, and that people from some countries are not sufficiently likely to become desirable Americans that we can afford to chance the entry of more than a hundred or two a year. It is a serious matter when a majority of Congress votes in favor of an immigration law based on the assumption that mankind is divided into fixed breeds, some superior to others. On the contrary, as Edward Corsi has said: ${ }^{3}$

... recent studies of the social life of immigrants indicate that foreign-born Americans, regardless of their country of origin, have a record equal to the native-born with respect to the major attributes of citizenship-obedience to law, occupational adjustment, educational level, health, family life, and citizenship.

Proponents of the present legislation have said they mean no "racial discrimination," but rather are concerned because cultural diversity makes it too difficult for some groups to assimilate. This is sheer camouflage for racism-else why may Brazilians of Portuguese or Indian ancestry come in without restriction, while Brazilians of Japanese ancestry must enter only under the Japanese quota? The

* B.A. 1933, Trinity University; M.A. 1938, University of Texas; Ph.D. 1941, University of Nebraska Professor of Sociology, Grinnell College. Formerly President, Midwest Sociological Society; Editor, Midwest Sociologist. Author, Spanish-Speaking Peoples in the United States (1954), and articles on ethnic group problems in sociological periodicals.

${ }^{1} 66$ STAT. I63, 8 U. S. C. \$\$ I10I-503 (I952).

${ }^{2}$ Act of May 26, I924, c. I90, 43 STAT. I53.

${ }^{3}$ Edward Corsi, Paths to the New Worid $24-25$ (1953). 
cultures of Australia and New Zealand are at least as like our own as is Britain's; yet, the former are limited to a quota of roo each, while Britain has a quota of over 65,000 . The culture of the Guatamala Indians is strikingly different from our ownnot even European in origin-yet, they are admitted without any numerical restriction. The Swiss have been found by almost every survey to average the highest in "culture" of any European nation; yet, we fear to admit over I700 a year.

No one argues whether or not our immigrants have furnished us manpower; what is questioned is the quality of immigrants and what they have contributed to our culture. Let us take, for example, the Italians. The Italian quota of some $5^{800}$ a year is far oversubscribed for many years to come, and we refuse to admit any additional Italians. By making a choice on such an irrelevant matter as nationality, we may well be excluding another famous musician like Arturo Toscanini, or a person like Mother Cabrini, the only United States Roman Catholic saint. Certainly, the bankers Giannini have made a tremendous contribution to business and industry on the West Coast, Angelo Patri to education, and Guiseppi Bellanca to airplane design and construction. Fiorello La Guardia, Judge Ferdinand Pecora, and Mayor Angelo Possi of San Francisco have made notable contributions in the field of public service. And the work of Enrico Fermi on the atomic bomb was outstanding. Can we not assume there are "more where those came from"? Bruno Rossi, Ugo Fano, Sergio De Benedetti, all physicists, and Piero Foa, prominent in experimental medicine, were able to get in under the quota recently, but how many like them are being excluded? Even the two immigrants who recently won (in opera) on The $\$ 64,000$ Question-humble shoemakers-gave pleasure to hundreds of thousands of other Americans and demonstrated a type of contribution Italian immigrants can make to American culture. All of this overlooks the greatest of all contributions which Italian immigrants have given us-their fine sons and daughters-of whom Pietro Di Donato (Christ in Concrete), Jimmy Durante, Frank Sinatra, and Joe DiMaggio are particularly well known, but who are unimportant when compared with the tens of thousands of business and professional men and good wives and mothers of Italian extraction.

In every area of our cultural life, we find recent immigrants or their children who have made distinctive contributions. For example, the music in America in r. 956 would be different-and poorer-if it were not for Leopold Stokowski, Arthur Rubinstein, Josef Hoffman, Artur Rodzinski, Jan Kiepura, and Leopold Damrosch, all of whom came to us from Poland; or Bela Bartok and Erno Rapee, from Hungary; Jose Iturbi, from Spain; Dimitri Mitropoulos, from Greece; and Arturo Toscanini, from Italy. The McCarran-Walter Act cut the already small quota of Austria, which sent us Fritz Kreisler, Leo Slezak, Bruno Walter, and Erich Korngold; it also cut the small quota of Russia, whence there came to us Sergei Koussevitsky, Andre Kostelanetz, Vladmir Horowitz, Sergei Rachmaninoff, Jascha Heifetz, Mischa Elman, Leopold Godowsky, Irving Berlin, and Igor Stravinsky. William 
Sweet points out ${ }^{4}$ that in 1930 , of the II4 members of the New York Philharmonic Orchestra, 84 were foreign-born. Equally important are the hundreds and hundreds of more pedestrian musicians who play in our orchestras, lead our small symphonies, teach music to us and our children, and who bequeath to their own children the great joy to be found in producing and listening to beautiful sounds. Yet, all these men came from countries with discriminatory quotas through which we rather effectively prevent very many others like them from sharing their talents with us.

The small-quota countries have also made an impact on the American theatre and motion pictures. From Hungary came Adolph Zukor, William Fox, and Academy Award Winner Paul Lucas; from Finland, Marion Nixon; from Poland, Pola Negri, Gilda Gray, Helena Modjeska, Paul Muni, and the Warner brothers; Austria sent Erich von Stroheim, Luise Ranier, Paul Heinreid, Elissa Landi, and Hedy Lamar. In the ballet, Russia has sent us so many dancers of such high quality that the Russian influence is predominant in ballet in America today. Few of our famous ballerinas were born in America.

Europe has always had a much greater reputation for painters than has America, so it should be no surprise that many artists who have made their mark in America have come to us from abroad. Not all have had the flamboyant showmanship of Spanish Salvador Dali or the talent of Luis Quintanilla, also of Spain. There have been, however, a large number of very capable and talented professional artists like Jonas Lie, of Norway, Albert Operti, of Italy, Emil Carlsen, of Denmark, William Ritschel, of Germany, Emile Walters, of Iceland, Leonard Ochtman, of Holland, J. Paul Verrees, of Belgium, Hovsep Pushman, of Armenia, and Nicholas Roerich, of Russia. Yet, as in the case of music, even more valuable and extremely greater in numbers are the nonprofessionals, for whom art is a hobby or a part-time occupation, but who have contributed much to the increase in American appreciation of artistic endeavors.

Within the arts, the field of sculpture ${ }^{5}$ has never been an especially popular one in America, which may or may not account for the fact that immigrants have been our most prominent sculptors for over one hundred years. Earliest and most famous of all was French-Irish Augustus Saint-Gaudens. Among the many famous statues he created are the Memorial to Colonel Shaw on Boston Common, the equestrian statue of General Sherman in New York's Central Park, the symbolic figure at famous Rock Creek Cemetery, Washington, D. C., the Abraham Lincoln statue in Lincoln Park, Chicago, and numerous other fine works. Karl Bittner, of Austria, is responsible for the famously beautiful bronze doors of New York City's Trinity Church. He also was director of sculpture at the Pan-American Exposition, the Louisiana Purchase Exposition, and the Panama-Pacific Exposition; he conceived and executed the Jefferson Monument at the University of Virginia and the Carl Shurz

\footnotetext{
4 Sweet, Cultural Pluralism in the American Tradition, il CHRIstendom 501 (1946).

The following material on sculpture, graphic arts, and handicrafts is drawn almost cntircly from Allen H. Eaton, Immigrant Gifts to American Life c. 6 (1932).
} 
Monument in New York City, as well as numerous other statues; and was twice president of our National Sculpture Association. Philip Martiny, of Alsatian-French ancestry, is especially noted for his World War I soldiers memorials, of which the Soldiers and Sailors Monument in front of City Hall in Jersey City is an example. Max Kalish, of Poland, produced the famous railroad statue, "Figure of the Oiler," which has been reproduced and popularized by the railroad industry. Albin Polasek, of Czech origin, was director of sculpture at the Chicago Art Institute. And the six Piccirilli brothers, of Italy, were all fine professional sculptors, as were Trygve Hammer, of Norway, David Edstrom, of Sweden, and George J. Zolnay, of Rumania.

In the area of the graphic arts we have received the talents of men like cartoonist Arthur Szyk, of Poland, upon whose head Hitler put a price, Rudolph Ruzicka, of Czechoslovakia, Julius O. Norfeldt, of Sweden, William A. Levy, of Russia, W. T. Benda, of Poland, Willy Pogany, of Hungary, Joseph Urban, of Austria, and Hendrik van Loon, of Holland. The varied fields of handicraft art have shown a high proportion of artists following in the footsteps of Duncan Phyfe, himself a Scotch immigrant. There has been Louis Rosenthal, of Lithuania, whose work in precious metals has been compared to Cellini's, I. Kirchmayer, of Austria, Adam Dabrowski, of Poland, Karl von Rydingsvard, of Sweden, Samuel Yellin, of Poland, Hunt Diedrich, of Hungary, Nicola D'Ascenzo, of Italy, Pauline Fjelde, of Norway, and Anna Ernberg, of Sweden. Even in such a mundane matter as the designing of money, immigrants have played an important role: the Lincoln penny was designed by Victor Brenner, from Russia; the dime and half-dollar by Adolph Weinman, an engraver from Germany; the silver dollar was designed by Anthony de Francisci, a native of Italy; Augustus St.-Gaudens, French-Irish designer and sculptor, designed the \$ro and $\$ 20$ gold pieces; and the green coloring matter in paper currency was invented by an immigrant named Seropian, from Armenia.

To evaluate the present situation in the field of the fine arts, let us take the case of John Vassos from Greece, whom Adamic describes as ${ }^{\circ}$

... one of the most versatile men under the sun: painter, sculptor, author, book illustrator, inventor, designer of stoves, cosmetic containers, automobile bodies, harmonicas, radio cabinets, turnstiles in the Empire State Building, Coca-Cola dispensers . . . [and] a lieutenant colonel in the Office of Strategic Services.

If John Vassos wished to come to the United States today, the obstacles would be well-nigh insuperable. The Greek quota is only 308 , and that has been mortgaged by half until the year 20r3, so that of the approximately 24,000 Greeks who are on the waiting list for quota numbers, only I54 a year may enter. If, despite these terrific odds, John Vassos' place on the waiting list was such that he might hope for a quota number next year, then he would have to obtain a clearance from the United States Employment Service, get written statements from some labor organization, submit

- Louts adamic, a Nation of Nations 28i (1945). 
affidavits from persons having special knowledge of him, assemble clippings of American advertisements calling for the services he claims to be able to render, and produce certified copies of diplomas, school certificates, and similar documents.

In the field of scholarship and education, the "undesirable" low-quota European countries have given us the famous psychologist, Franz Alexander, and John von Neumann, Princeton mathematician and Atomic Energy Commissioner, both from Hungary. Poland has sent us Alfred Korzybski, world-famous founder of General Semantics, Bronislaw Malinowski, equally famous in anthropology, best-seller author Sholem Asch, and Florian Znanecki, past-president of the American Sociological Society. Austria gave us Edward A. Steiner, educator, author, and lecturer, and Felix Frankfurter, law teacher and Supreme Court Justice. From Hungary also came Joseph Roucek, prominent sociologist, and that titan of journalists, Joseph Pulitzer, whose contributions to America were so great that he was honored with a commemorative stamp. From Yugoslavia came author Louis Adamic and Henry Suzallo, president of the University of Washington and of the Carnegie Endowment for the Advancement of Teaching (founded by an immigrant from a more favored country). Constantine Panunzio, sociologist, came from Italy; Pitirim Sorokin, head of the Harvard Sociology Department, is from Russia; and Ales Hrdlicka, the "grand old man" of American anthropology, came from Bohemia. Norwegian-born Thorlief Hegge, Director of Research at Wayne County Training School, has made contributions in the field of psychology and the study of mental defectives with personality problems. Hans F. Blichfeldt, who came from Denmark as a boy, became a Stanford University mathematician of international fame. Z. W. Birnbaum, from Poland, is Director of the Laboratory for Statistical Research at the University of Washington.

In the field of medical arts and research, the story is the same. Bulgaria, from within her tiny quota, sent us Dr. Strashimer Petroff, who made great contributions to the control of tuberculosis bacteria. From Armenia came Dr. Minas Gregory, for over twenty years head of the psychiatric department of Bellevue Hospital. From Hungary came Joseph Strasney, pathologist and hematologist, whose research aids in the battles against cirrhosis of the liver, the anemias, infectious mononucleosis, lymphoblastoma, and cancer; Balint Orban, who came from Hungary in the thirties, has made contributions in the field of the histopathology of dental tissues, the histology of gingiva, and periodontal disease; Paul Gyorgy, now Professor of Clinical Pediatry, University of Pennsylvania, has done useful research in the fields of nutrition, metabolism, riboflavin, pyridoxine, biotin, and hormones; Irme Horner has made contributions in the fields of physiological chemistry, immunology, and internal medicine and is a specialist in the lipoids of the liver; Andros Angyal, who came from Hungary in 1932, is a famous psychiatrist whose specialties include the psychology of dream and hypnagogic states, sensory neurology, and the psychiatry of schizophrenia; Tibor Benedek's contributions have been in the field of mycology,

${ }^{7}$ See Consi, op. cit. supra note 3 , at 35 . 
medical bacteriology, and dermatology; and the Bela Schick has led the fight against diphtheria. Especially significant is the fact that Hungary sent us one hundred per cent of her Nobel Prize winners, in the person of Albert Szent-gyorgyi, worldfamous for his medical researches in heart disease and muscles.

Austria, with her tiny quota, has sent us a disproportionate number of medical researchers. Hans Neurath, Professor of Physical Biochemistry at Duke University, has done much research in the chemistry of enzymes and proteins, in immunochemistry, and in the serologic diagnosis of syphilis; Paul F. de Gara, after less than twenty years in America, is a famous pediatrician who, for his research, has specialized in typhoid fever, undulant fever, tuberculosis, pneumonia, and antibodies; Leo Alexander, psychiatrist, has conducted research in the fields of neuropathology and electroencephalography; Wilhelm Rood, already well known before he emigrated, is an expert in the field of pituitary gland functions, thyrotoxicosis, hyptertension, neurohormones, heart disease, and the treatment of angina pectoris by $\mathrm{x}$-ray irradiation; Karl Sollner, who came from the Austrian Public Health Service to the United States Public Health Service, is a research chemist specializing in colloids; Alfred Adler is one of the world's greatest research psychiatrists; and Dr. Karl Landsteiner has won a Nobel Prize for his medical research.

From Italy came Piero Foa, now of the Chicago Medical School, who has made valuable studies in arterial hypertension, insulin, secretion, chlorine deficiency, bone marrow metabolism, and other areas of experimental medicine. From Spain has come Severo Ochoa, whose studies in medical biochemistry include respiratory enzymes, the biochemistry of muscles, and the enzymatic mechanisms of carbon dioxide assimilation. Ludwig Anigstein, from Poland, is famous in the field of preventive medicine, two of his specialties being tropical diseases and rickettsial diseases and infections; Bernard Gottlieb, from Poland, has made significant studies of dental caries and pyorrhea; Richard $\mathrm{K}$. Richards, who also came from Poland, is now Director of Pharmacological Research for Abbott Laboratories, specializing in local anesthetics, hypnotics, anticonvulsants, toxicology, and metabolism. From Sweden came young Otto Folin, who taught for many years at the Harvard Medical School and of whom it was said: 8

... from his own ingenious methods and the wisdom of his approach to important biochemical problems ... has grown the whole range of the microchemical analyses of the blood and other body fluids which are daily in use in ... hospitals and ... doctors' offices the world over.

Particularly significant is the fact that in the great majority of the above cases the mother country bore the entire burden of rearing, training, and nurturing the talent of these men, sending them to us, usually at the full height of their usefulness, as a free gift.

In no area more than natural science have immigrants from the "discriminated

827 National Academy of Sciences, Biographical Memorrs 48 (r952). 
against" countries made such a contribution to American culture, and no more striking example exists than the study of atomic power. Atomic scientists Teller, Szilard, and Wigner came from Hungary, as did the parents of David Lilienthal, former chairman of the United States Atomic Energy Commission; from Italy came Fermi, Rossi, Fano, and de Benedetti; Hecht, Adler, Benesi, Beth, and Hess were from Austria; Fajans, Smoluchowski, and Mrozowski were from Poland; Bloch came from Switzerland; and Debne from the Netherlands.

Carl Wittke, in We Who Built America, says, "Perhaps the three greatest 'electrical wizards' of this age of electricity were Charles P. Steinmetz (German) . . . Michael Pupin, who came to the United States as an illiterate Serbian boy; and Guiseppi Faccioli, a native of Rome. ..."ㄱ In the field of aeronautics, we are greatly indebted to Guiseppi Bellanca, from Italy, and even more to Igor Sikorsky, Boris Sergievsky, and Alexander Seversky, of Russia. We have been the recipients of especially outstanding immigrant gifts in the field of electricity and radio. For example, from Alexander Georgiev, of Bulgaria, we received the condenser used in all radios and electric motors; Yugoslavian Michael Pupin, of Columbia University, made a wide variety of inventions and advances in the field of wireless telegraphy and the long distance telephone, as well as inventing the "tuning in" device used on every radio; and even more important was Nikola Tesla, also of Yugoslava, among whose over 700 inventions was the polyphase induction electric motor, and of whom Adamic says: ${ }^{10}$

Were we to eliminate from our industrial world the results of Tesla's work, the wheels of industry would cease to turn, our electric trains and cars would stop, our towns would be dark, our mills and factories idle. So far-reaching is his work that it has become the warp and woof of industry.

Another Yugoslavian of importance was Frank Jaeger, who revolutionized the honey industry. Lucus Kyrides, from Greece, is very prominent in industrial chemistry. Walter Mayer, famous collaborator on the Einstein-Mayer theory, was born in Hungary. From Poland came Casimir Funk, who has benefited our whole population through his discovery of vitamins. Bulgarian-born George Dimitroff is in charge of the Harvard University Observatory. Pol Swings, from Belgium, is world famous in astronomy, astrophysics, upper-atmosphere physics, and applied spectroscopy. Sergei Gaposchkin, Russian-born astronomer, has as his specialties variable stars, eclipsing binaries, and stellar photometry. Conrad Victor, from Austria, has made special studies of the seismograph for earthquakes. And Jacob Bjerkne, from Sweden, also a meteorologist, has worked with the United States Weather Bureau and made discoveries in the scientific foundations of weather forecasting.

In the field of chemistry, one of our most noted immigrants is Peter Debye, from the Netherlands, head of the Cornell University Chemistry Department, who has re-

- Carl Wittke, We Who Built america 393 (1940).

${ }^{10}$ ADAmic, op. cit. supra note 6, at $24 \mathrm{~T}$. 
ceived not only the Rumford, Faraday, Lorenz, Franklin, and Gibbs medals, but also the Nobel Prize in chemistry; his special fields are physical chemistry and molecular structure. Austrian-born Walter Berl has made contributions to his adopted country in the fields of synthetic fuels, electrochemistry, explosives, and guided missiles. Kasmir Fajans, prominent Polish-born physical chemist, has made discoveries in radioactivity, isotopes, thermochemistry, photochemistry, light absorption, refractivity, and the structure of glass. Hans Benesi, from Austria, chemist at the University of California, is probably best known for his work with the Atomic Energy Commission and the Office of Naval Research, but he has also made important contributions in the fields of calorimetry and dielectric measurement. Poul Hansen, from Denmark, Professor of Bacteriology at the University of Maryland, has done outstanding work in the fields of mastitis, thermophilic and lactic acid bacteria, cheese ripening, and bacterial fermentation. Karl Bloch and Walter Fuchs are both Austrian-born chemists; the former's main field is printing inks, and the latter's are fuel technology and organic, lignin, and coal chemistry.

Among our foreign-born physicists, Enrico Fermi is particularly prominent; born in Italy and winner of a Nobel Prize in physics, his major fields were atomic structure, atomic nuclei, beta-ray emission, artificial radioactivity by neutron bombardment, slow neutrons, and chain reaction. Also very important in atomic physics is Austrian-born Victor Hess, now at Fordham University; winner of a Nobel Prize in physics, his major contributions have been in the fields of cosmic rays, radioactivity, atmospheric electricity, and the refractive indices of mixtures of liquids. Edward Teller, from Hungary, is now a professor at the University of California and is best known for his work with the United States Atomic Energy Commission in molecular and nuclear physics. Felix Adler, from Austria, is a mathematical physicist whose contributions have been in neutron diffusion and in various aspects of theoretical physics. Felix Bloch, Swiss-born professor of physics at Stanford University, worked on the Manhattan Project during the war and has made advances in the fields of electron theory, $x$-rays, polarization of neutrons, and atomic nuclei. Sergio De Benedetti, from Italy, has worked at the Oak Ridge atomic plant; his major research has been in nuclear physics, cosmic rays, radioactivity, and the emission of positrons. Ugo Fano, also from Italy, has worked on ballistics for the army and done research for the United States Bureau of Standards, and is best known for his work in nuclear physics, theoretical spectroscopy, and his theory of diffraction and of propagation of radiations through matter and its effects on matter. Stanislaw Mrozowski, originally from Poland and now at the University of Buffalo, is best known for his work on atomic and molecular spectra, isotope shifts, and carbon and graphite properties. George Jaffe, born in Russia, has done special work in theoretical physics and in the conductivity of liquid and solid dielectrics. Bruno Rossi, who has worked at Los Alamos and is a cosmic ray specialist now at the Massachusetts Institute of Technology, was born in Italy. Atomic physicist Roman Smoluchowski, from Poland, has worked for the Navy and 
for the Atomic Energy Commission and specializes in radioactive tracers, $\mathrm{x}$-rays, and magnetism. Henri Sack, whose chief contributions have been in the fields of supersonics, infra-red spectroscopy, and the electrical computation of elasticity of solids, was born in Switzerland. Otto Redlich, from Austria, has experimented with the hydration of cement, alumina from clay, molecular vibrations, and thermodynamics. Eric Beth, also originally from Austria, has made contributions in electronics, wave mechanics, astrophysics, cosmic radiation, and upper-air properties.

Since 1924, there have been certain countries "favored" by our immigration legislation. Chief among these are England, Ireland, and Germany. The immigrants from these three countries have been numerous and have made great contributions to the present state of the arts and sciences in America. The author believes, however, that these contributions should not be included in this paper, for the large quotas these countries have means that they enjoy relatively free immigration under existing conditions. This is not to minimize these contributions, but rather reflects an assumption that the present legislation does not hinder such contributions. Among the "favored" countries there are many which have small quotas, too. Often these quotas have not been filled to capacity; yet, in their arbitrary limitation remains the implication that we would refuse to accept any appreciable number of people from these countries should they choose to emigrate. For example, Finland

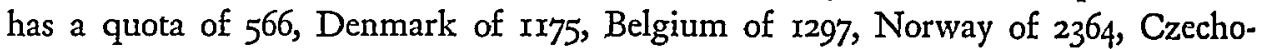
slovakia of 2859, France of 3069 , Netherlands of 3136 , and Sweden leads the list with a munificent quota of 3295 . If our previous thesis is sound-that those countries with low quotas have made a significant contribution to American culture through their emigrants-then this should hold true of other countries with low quotas, even if these quotas are proportionately high. ${ }^{11}$ By way of illustration, let us very briefly examine a few such countries.

Danish immigrants settled chiefly in Iowa, Minnesota, Nebraska, and Wisconsin, and it is this geographic area in which their impact has been most felt. In considerable proportion, they have been farmers, but they had and continue to have a high educational level and have been pioneers in the scientific aspects of agriculture and dairying. Danes have added to the quality of the products of the bakery business throughout the Midwest; prominent industrialists include Nils Paulsen, inventor and manufacturer of fireproof stairs and of library bookstacks, William Knudsen, of General Motors, and George Rasmussen, founder of the National Tea Company. Jean Hersholt and Victor Borge became famous entertaining millions;

${ }^{11} \mathrm{By}$ "proportionately high" is meant in relation to their home population. For cxample, Norway, Sweden, and Denmark together have a population of about $14,400,000$ and a combined quota of 6834 , while Rumania, with a population of about $16,000,000$, has a quota of only 289 ; Bulgaria, with a population of about 7,000,000, has a quota of 100, while Eire, population 3,000,000, has a quota of 17,756! Little Nauru, eight square miles and a population of 2855 , can send as many emigrants as India. What our present law says, in effect, is that those countries which by a historic accident scnt us large numbers of immigrants may continue to do so; conversely, those which by historic accident sent us few immigrants are not permitted to send any appreciable number, regardless of the changes which have occurred or may occur; and all this with but little regard to the quality of the persons sceking admittance. 
but even more important has been Jacob Riis, the immigrant journalist whose writings did so much to make America aware of the fields of child labor, slum housing, and recreation, and whom Theodore Roosevelt called "the most useful American of his day." Previously mentioned Danish immigrants include Poul Hansen, agricultural bacteriologist, Pol Swings, astronomer at McDonald Observatory, and Hans Blichfeldt, Stanford mathematician.

Belgian immigrants settled chiefly in Michigan, Illinois, and New York, and about half of them live in rural areas today. Many are skilled as truck gardeners and farmers; others have gone into the textile industry, especially the silk mills; still others have become cooks, bakers, and butchers. They, too, have their share of prominent men; General Goethels, of Panama Canal fame, was of Belgian descent; Andre Parmentier, an immigrant, is one of the founders of landscape gardening in America; Father Nieland, through his discovery of synthetic rubber, made an immeasurable contribution to our war effort in World War II; Dr. Leo Baekeland is world famous for his many inventions, especially bakelite and other plastics and Velox photographic printing paper, which helped bring amateur photography within the range of any school boy.

The Dutch settled primarily in Michigan, Iowa, and Illinois. The great stability and prosperity and the general esteem in which such Dutch settlements as Holland, Michigan, and Pella, Iowa, are currently held is an indication of the industry and citizenship of Dutch immigrants. They have been strongly religious and deeply interested in education. Particularly prominent in this group are Pulitzer Prize winner Edward Bok, immigrant editor, publisher, and author, and Hendrick Willem van Loon, noted author and artist. Paul De Kruif and Pierre van Paassen, both of Dutch parentage, are best-selling authors. "There is scarcely an observatory in the United States without an astronomer of Dutch origin or descent. And there is hardly a university or college that hasn't one or more professors of the same stock."12 Peter Debye, Nobel Prize winner, has been mentioned previously.

Most of the Swedish immigrants settled in the northcentral states, and their chief contributions have been in that region. Highly literate and mechanically inclined, they have produced a large number of skilled craftsman who, in turn, have produced numerous inventions. Among the scientific advances due to persons from Sweden or of Swedish descent are the automatic elevator, invented by David Lindquist, chief engineer for Otis Elevator Company, and the numerous automotive advances made by Victor Bendix, including the Bendix spring, which made possible automobile self-starters. Gideon Sundback invented the zipper, and Alexander Anderson invented the method used in making "puffed" cereals. E. F. W. Alexanderson, of General Electric, has produced over three hundred inventions in the fields of radio, power, transportation, and electricity. It was Carl D. Anderson, of California Institute of Technology, who discovered the positron, and John A. Udder who opened the Texas oil fields. Swedes also had much to do with the discovery or

\footnotetext{
${ }^{12}$ ADAMrc, op. cit. supra note 6 , at 120 .
} 
improvement of such diverse products as Celotex, special ball bearings, cream separators, and all-steel bodies for automobiles. Stromberg and Carlson, who have done so much in radio and allied fields, are both Swedes. Previously mentioned have been Otto Falin, world-famous for his medical research, and Jacob Bjerkne, outstanding meteorologist.

Professors who are Swedish or of Swedish descent are relatively common in American colleges and universities. Possibly one of the best known is Carl E. Seashore, noted psychologist. Equally well known is physiologist Anton Carlson, professor emeritus of the University of Chicago, who has published hundreds of research reports on alcoholism, hunger, nutrition, infantile paralysis, and has served as president of a number of national physiological organizations. In the entertainment field, there are Warner Oland, creator of Charlie Chan roles, Anna Q. Nilsson, and Greta Garbo. Carl Sandburg and Edgar Bergen are both of Swedish parentage.

Although relatively large numbers of Norwegian immigrants never came to America, those who did have made a signal contribution to American life. This has been especially true in the field of education. According to O. M. Norlie, ${ }^{18}$ in one hundred years in America, the Norwegians set up one hundred institutions of higher learning. Of those which remain, probably the best known are Concordia, Luther, St. Olaf's, and Augustana Colleges. During the I890-1925 period, Norwegians produced three state superintendents of schools, eleven college or university presidents, a number of deans, and professors at most of the midwestern state universities as well as numerous smaller colleges. Some of the most prominent of these educators have been Thorstein Veblen, in economics and sociology, Thorleif Hegge, in educational psychology, Svendrup and Holmboe, in meteorology, C. A. Elvehjen, whose discoveries led to the use of nicotinic acid in treating pellegra, and $\mathrm{E}$. $\mathrm{O}$. Lawrence, who received a Nobel Prize in physics and worked on the atomic bomb. No less outstanding a teacher in his own way was immigrant Knute Rockne, famous as the Norwegian who used Polish boys to make the "Fighting Irish" the nation's leading football power. Norlie estimates that during this period, in the field of nonfiction, at least a thousand books dealing with some branch of theology were published, in addition to one or more books by Norwegian authors in the fields of biology, physics, chemistry, astronomy, geology, ethnology, physiology, medicine, dentistry, agriculture, business, military science, law, sociology, economics, library science, art and architecture, travels, philology, literary criticism, engineering, mathematics, statistics, education, musical theory and history, and psychology.

In the field of the arts, Norwegians have been particularly prolific in music and in literature. Few Norwegians in America have been outstanding musicians, but a great number have been deeply enough interested in music to compose it, to direct bands, glee clubs, choirs, and orchestras, and so to gain either local or regional recognition. Norlie lists hundreds of such musicians active in 1890-1925, most of

\footnotetext{
${ }^{13}$ Most of the information on the Norwegians is drawn from O. M. NorLIE, History on thrE Norwegian People in America (1925).
} 
them immigrants. He also names fifty Norwegian poets who put on the market one or more volumes of verse, and reports that over one hundred others have published works of fiction.

The Norwegian relationship to the arts seems to be typical of that of most immigrant groups in that while they produced a few outstanding talents, they made their real contribution not in leaders, but in highly essential followers. It has been true through most of our history and into the present time that the groups interested in and appreciative of painting, sculpture, the dance, drama, and vocal and instrumental music of a high quality have been immigrants or the children of immigrants. The contribution of this large group of sympathetic, understanding, and enthusiastic followers has been to all forms of artistic endeavor and has lent strength and both psychological and financial encouragement to professionals in these fields.

It is rather generally agreed that one of the important contributions which immigrants make is that they often are fully trained when they arrive. Thus, the receiving country acquires all the benefit of their talents and skills which come as gifts from the country of their origin. Nowhere is this more evident than in the case of the refugees admitted to America during the war and post-war period. This group is particularly relevant because it was the very inadequacy of our immigration program and the inability of these people to come to us under that program that caused the passage of emergency refugee legislation. Maurice $\mathrm{R}$. Davie, with collaborators, in Refugees in America ${ }^{14}$ has given us a comprehensive study of this group.

Hundreds of professors and scientists came to us in the I930's and I940's, about half of them finding positions here in the same occupation of their training and experience. Law, physics, medical science, language and literature, chemistry, economics, mathematics, history, and philosophy are, in order, the chief fields of these scholars. The New School for Social Research, for example, has a faculty principally of refugee scholars and has proved itself an outstanding institution of higher education. According to Davie, ${ }^{15}$ over 300 of these refugees were, by I946, already listed either in American Men of Science or Who's Who in America. Among this group were thirty-eight physicists, six of them Nobel Prize winners, thirty-eight chemists, including two Nobel Prize winners, forty-two mathematicians, fifty-eight persons in the medical sciences, fifteen in the biological sciences, including a Nobel Prize winner, nine astronomers, eight psychologists, seven meteorologists, twelve social scientists, and four engineers.

During the war, these scientists did yeoman service for their adopted country. No less than nine of them worked in the field of atomic energy and made direct contributions to nuclear fission. In a different field, Dr. Ernst Berl, chief chemist for Austria-Hungary in World War I, did much for America during World War

\footnotetext{
"Maurice R. Davie, Refugees is America (1947). The material on refugees is chiefly drawn from this source.

${ }^{15}$ Id. at 322
} 
II, plus his peacetime development of a method of artificially producing coal and oil.

In the arts, we received a like contribution from our adopted citizens. A sample of refugee writers studied by Davie contained eighteen listed in Who's Who in America, including Maurice Maeterlinck, Sigrid Undset, and Thomas Mann, who were Nobel Prize winners.

The presence in this country of such men as Emil Ludwig, Franz Werfel, Stefan Zweig, Ferenc Molnar, Richard Beer-Hoffmann, Walter Mehring, Joseph Wittlin, Berthold Viertel, Egon Hostovsky, Lion Feuchtwanger, Erich Maria Remarque, Jules Romains, Alfred Polgar, Erich Kahler, Herman Broch, Paul Scheeker, Fritz von Unruh and Konrad Heiden has added luster to the American literary scene. ${ }^{16}$

Some have already published works of great significance since their arrival, some are teaching, some are working as writers for motion pictures, television, or magazines. Many of them worked during the war in OWI or OSS.

Varian Fry, writing about this group of literary refugees says: ${ }^{17}$

Not that there would have been any dearth of books ... if they hadn't come. But it is ... good to know that so many of them have had considerable success. It shows not only how much opportunity America still has to offer the newcomer to its shores; it shows also how much the newcomer to its shores has to offer to America. It was no purely humanitarian gesture of ours to let these people in. We profited enormously from it. We got some of the best minds Europe has produced in a generation.

In music, we have recently been the recipient of such talents as those belonging to Arturo Toscanini, Bruno Walter, Wanda Landowska, Lotte Lehman, Ernst Krenck, Jaromil Weinberger, Darius Milhaud, Jarmila Novotna, and John Garris. Possibly of even more importance are the large numbers of yet unknown young musicians who brought the beginnings of their talent to this country and some of whose names in future years may be among our most illustrious. There were also a very large number of skilled but not brilliant musicians who are now employed as music teachers either in schools or privately.

Many of the refugee stage and screen performers found ready acceptance here. Examples are Oscar Karl-Weiss, Mady Christians, Oskar Homolka, Albert Bassermann, Sig Arno, Edith Angold, Adrienne Gessner, as well as directors and stage managers Paul Czinner, Otto Preminger, Erwin Piscatar, Herbert Graf, Berthold Viertel, and Max Reinhardt. Hans Kafka, in his "What Our Immigration Did for Hollywood-and Vice Versa"18 listed some ninety refugee screen actors, thirty-three directors, twenty-three producers, fifty-nine screen writers, and nineteen composers for films.

The editor of the multi-volume Dictionary of American Biography, Dumas Malone, is much interested in the effects of immigration on American culture; he re-

${ }^{16} I d$. at 344 .

${ }^{17}$ Fry, What Has Happened to Them Since, I47 Pubushers' WeerLy 2434, 2437 (1945).

${ }^{18}$ Kafka, What Our Immigration Did for Hollywood-and Vice Versa, Aufbau, Dec. 22, 1944. 
ports $^{19}$ that twelve and one-half per cent of the subjects in that Dictionary were born outside the United States. Since the proportion of foreign-born in our population ranges from ten to fifteen per cent, it would appear that the foreign-born have been almost exactly as successful as the native-born. This is an even more remarkable record considering the language handicap which so many of the foreign-born must overcome, plus the fact that a large number of the persons represented in the Dictionary of American Biography have been prominent in the field of politics and statesmanship, one in which the foreign-born would have a serious handicap. It is worthy of note, says Malone, ${ }^{20}$

... that our immigrants have done their proportionate part and that they have attained distinction, not often in politics of war, not primarily in business, but chiefly in literature, and the fine arts, in religious leadership, science and learning. . . . Into the American crucible our immigrants have poured not merely their brawn, but also their spiritual aspirations, their talents, and their brains.

In general, these are the findings, too, of the President's Research Committee on Social Trends, which found that the distinction achieved by the foreign-born group as a whole, through the year I929, was "remarkable," in view of its relative size. ${ }^{21}$

Possibly the most significant statistical study made of the role played by immigrants in the field of science is contained in a report by Stephen S. Visher. ${ }^{22} \mathrm{He}$ found that between I903-I943, approximately 2600 persons in American Men of Science had been "starred" by vote of their colleagues as being leaders in research in their respective fields. Since to be starred your contributions must have occurred while in America, it is highly significant that about one-sixth of those starred were foreign-born. Of the total number of men starred in mathematics, thirty-one per cent were foreign-born; in anthropology, it was twenty-two per cent; in astronomy, twenty per cent; foreign-born represent about one-sixth the totals in chemistry, physics, physiology, and psychology; and there were lower, but still significant, percentages in anatomy, botany, and geology.

By using Visher's data as a basis, it is possible to make a reasonably adequate comparison of the relative proportions of foreign-born and American-born starred scientists. Despite the fact that complete accuracy would require an assessment of dates of birth, the analysis, nevertheless, shows clearly that scientists from lowquota countries have acquitted themselves very well. The countries whose immigrants clearly appear proportionately to outstrip native-born Americans include Austria, in anthropology, astronomy, chemistry, mathematics, pathology, physics, physiology, and zoology; Hungary, in geology, mathematics, and physics; Netherlands, in astronomy, chemistry, geology, mathematics, physics, and physiology; Russia, in astronomy, mathematics, pathology, physics, physiology psychology, and

${ }^{10}$ Malone, The Intellectual Melting Pot, 4 AM. Scholar 444, 446 (1935).

so Id. at 459 .

31 President's Resenach Committee on Social Trends, Recent Social Trends 553 (i933).

${ }^{22}$ Stephen S. Visher, Scientists Starked, 1903-I943, in "American Men of Science" $386-92$ (1947). 
zoology; Scandinavia, in anatomy, anthropology, astronomy, chemistry, and mathematics; and Switzerland, in anthropology, astronomy, chemistry, mathematics, pathology, physics, physiology, psychology, and zoology.

All in all, the facts are clear. Our immigrants from the small-quota countries have made significant and valuable contributions in the arts and sciences. Outstanding illustrations show the high quality of many of these immigrants, but of equal or more importance are the "nonprofessionals" in these fields who bring with them a love of learning and of beauty in whatever form it may be found. This leavening influence may well be their greatest contribution to America. 